This is a self-archived - parallel published version of this article in the publication archive of the University of Vaasa. It might differ from the original.

\title{
Institutional Logics and Their Influence on Enterprise Architecture Adoption
}

Author(s): Dang, Duong

Title: $\quad$ Institutional Logics and Their Influence on Enterprise Architecture Adoption

Year: $\quad 2019$

Version: Accepted manuscript

Copyright (C) 2019 Taylor \& Francis. This is an Accepted Manuscript of an article published by Taylor \& Francis in Journal of Computer Information Systems on 17 Jan 2019, available online: http://www.tandfonline.com/10.1080/o8874417.2018.1564632

\section{Please cite the original version:}

Dang, D. (2019). Institutional Logics and Their Influence on Enterprise Architecture Adoption. Journal of Computer Information Systems. https://doi.org/10.1080/o8874417.2018.1564632 


\title{
Institutional logics and their influence on enterprise architecture adoption
}

\begin{abstract}
Enterprise architecture adoption (EAA), often ironically known as "ineffective adoption," is frequently marked by poor utilization and signals of failure. To date, comprehensive examinations of which factors influence EAA are lacking. This study aims to address this knowledge gap. The paper uses an interpretive multiple case-study approach using an institutional theory lens to conduct the research. The findings show that three institutional logics dominate EAA: managerialism, professionalism, and user logic. These logics drive stakeholder activities and behaviors and ultimately influence EAA processes and outcomes. The paper contributes to the literature by explaining how these three logics influence the adoption process. Practitioners will be able to use the logics discussed in this study to assess and prevent potential challenges to adoption by carefully examining the stakeholder behaviors and activities embedded in these logics.
\end{abstract}

Keywords: enterprise architecture, enterprise architecture adoption, institutional theory, institutional logic, case study, interpretive approach 


\section{Introduction}

Although numerous organizations use enterprise architecture (EA) as an approach to aligning business processes with strategic management, information systems (IS), and IT consolidation and planning [1-4], practitioners often struggle when adopting EA into their organizations $[5,6]$. The challenges they face include the complexity of the EA concept $[6$, 7], the human resources necessary for EA implementation, and stakeholders' general lack of support for EA products [7-9], among others [16, 30, 31]. These challenges have led EA adoption, or EAA, to become ironically known as "ineffective adoption" and to suffer poor utilization and other signals of failure $[5,11,12]$.

Much research has been conducted on which factors influence EAA [13-16]. These studies have focused on particular phases, however, and they have yet to focus on the activities and behaviors of stakeholders who take part in or are otherwise affected by the EAA process. This paper argues that studying stakeholders' activities, behaviors, norms, and practices could provide insights into stakeholders' roles during EAA. Such an examination may help to illuminate why organizations with similar initial objectives, eco-political environments, and policies often obtain different outcomes during EAA. By understanding stakeholders' activities and behaviors, this study can also help practitioners to improve EAA in their practices.

Most studies have focused on the macro level (e.g., using the organization as the smallest level of the analysis); few researchers have conducted micro-level research, such as of individuals and groups $[7,17]$. Micro-level studies must be context-specific, thus limiting generalizability [17]. EAA can also unfold over years, which can obstruct research $[3,18]$. In the present work's micro-level analyses, we argue that such analyses will help to better understand macro-level phenomena, as such phenomena are often rooted in micro-level activities and behaviors [19]. The field of institutional logic provides a lens for micro-level 
examination and helps to understand the practices, assumptions, beliefs, and behaviors of individuals or groups, and consequently to understand their actions $[20,21]$ within broad social institutions [22].

When organizations adopt EA, stakeholders (either individuals and groups) will be involved in or influenced by the EAA process. This paper analyzes individuals' and groups' practices, assumptions, beliefs, and behaviors to understand their actions embedded in institutional logics and the influence of those logics on the EAA process. The research question is thus, "How do institutional logics influence the EA adoption process?"

The study uses an interpretive multiple case-studies approach using data from interviews, secondary data, and informal observations. The study contributes to the literature by identifying several institutional logics that appear in the EAA process and by explaining how these logics influence the adoption process and its outcomes. The study also has implications for EA practices, as the findings could help managers to prepare for and minimize any failures in adoption by paying attention to stakeholders' behaviors and activities embedded in the three logics.

The remainder of this paper is organized as follows. The next section describes the theoretical background, followed by the research methods. The subsequent sections present the findings chapter before moving on to the discussion section. The concluding section discusses the implications and limitations of the study as well as future research possibilities.

\section{Theoretical background}

\section{Enterprise architecture and relevant concepts}

Kaisler et al. define EA as the main components of an organization as well as its "information systems, the ways in which these components work together in order to achieve defined business objectives, and the way in which the information systems support the business 
processes of the organization" [8; p. 1]. Organizations adopt EA for many purposes, such as business and IT alignment, strategic management, and IT consolidation [2-4]. EA can potentially tackle problems related to efficiency, effectiveness, and interoperability that often plague organizations [23]. Many countries have adopted EA or similar programs, and some even have EA-related laws, as in Finland and the United States.

Various terms and views are used to describe the EAA process [24, 25]. For example, Iyamu (2009) uses “institutionalization of EA,” while Weiss et al. (2013) use "institutionalization of EA management" $[17,26]$. Although these authors use different terms, the EAA process can be understood as a process that brings EA functions or features to practices as a norm. Organizations usually adopt EA through projects, guides, or programs. To understand which factors influence EAA, this paper seeks to understand the behaviors and activities of stakeholders who are involved with or influenced by EA projects.

Rahimi et al. describe enterprise architecture management (EAM) as "a management approach that helps organizations plan, develop, and control their enterprise architecture in a coordinated and purposeful manner by providing a holistic understanding of the EA ... and ensuring that the organization adheres to EA principles" [27; p. 125]. In that sense, EA projects and their activities may be seen as part of EAM. As Freeman argues, stakeholders may be identified as "any group or individual who can affect or is affected by the achievement of the organization's objectives" [28; p. 46].

\section{Literature review}

\section{EA adoption research}

The EAA literature focuses on problems, frameworks, and concepts [2, 12, 29]. These studies have focused on unclear EA products, overly wide scopes, insufficient resources and limited tools $[1,8]$, unnecessary complexity $[1,6]$, among other problems $[16,30,31]$. While 
numerous studies have examined EAA in the literature, these studies have focused on particular phases, such as the design, implementation, or post-adoption stages $[10,13,15$, 32]. The literature has also identified several factors that influence EAA. For instance, various factors influence EAA, such as EA documentation, programming, planning, stakeholder participation, and architectural governance [15]. The success factors for postEAA stages include organizational anchoring and product, infrastructure, and servicedelivery quality [13]. Other factor influence EAA in general, including processes, communication, lack of awareness, actors' relationships, and policies [14]. These studies have yet to focus on the activities and behaviors of stakeholders who take part in or are affected by the EAA process, however.

Although previous studies have noted which factors influence EAA, they have not had much success in illuminating the entire EAA process $[13,15,33]$. Looking closely at the process helps to generate a complete picture of which factors influence EAA. Understanding these factors could help practitioners to improve the success rate of EAA, which is currently in a near-crisis condition [23].

\section{The institutional view of EA adoption}

Only a few studies have been conducted on the institutional view of EAA; these studies have focused on problems related to organizational structures, conflict benefits, and policies about institutionalizing EA during the initiation, planning, and implementation phases [7, 12]. Previous studies have also examined barriers to EA institutionalization, including economic investment, understanding EA, and technical capabilities [26]. Scholars have indicated several factors to influence the effectiveness of EA institutionalization, including trust, governance, social legitimacy, goal alignment, and organizational grounding [17, 34]. 
In a similar vein, government pressures and political motives drive EAA development $[35,36]$. Management is another factor to influence EAA in organizations $[37,38]$; the legitimacy of the EA framework and interoperability challenges are other key factors to influence EAA [39]. As noted above, these studies have either focused on certain factors or phases of EAA, or its problems; they have not revealed any inside adoption processes, such as whether stakeholder involvement influences outcomes and, if so, how. This study has scrutinized these matters for these reasons.

\section{Theoretical framework}

The study uses institutional theory as a lens. Institutional arguments are based on the common assumptions that institutions are governance structures, which embody rules for societal behaviors [40]. Organizations and groups conform to these rules to secure the resources and legitimacy crucial for their survival [40, 41].

Institutions are influenced by three main institutional pressures: regulative, normative, and cognitive-cultural [40-42]. These pressures lead to organizational forms, procedures, and activities becoming more similar to others in similar settings [41]. Regulative pressure indicates policies or regulations that institutions must obey or comply with. Normative pressure indicates how professional groups influence or drive institutions' stakeholders. Cultural-cognitive pressure refers to institutional culture, such as stakeholder backgrounds, education, and beliefs [40-42].

Thornton and Ocasio define institutional logic "socially constructed, historical patterns of material practices, assumptions, values, beliefs and rules by which individuals produce and reproduce their material subsistence, organize time and space, and provide meaning to their social reality" [21; p. 101]. Thus, institutional logic provides links between individuals and the world around them. As a result, institutional logic can help to understand 
material practices, assumptions, values, beliefs, and rules as well as people's legitimizing behaviors; their actions can then be understood [20, 21].

Institutional logics are characterized by several features. First, they occur on multiple levels; that is, they range from societal to individual levels, and these levels influence one another [21, 43]. Second, they are pluralistic and often contradictory [19]. Third, they are embedded within multilevel logics, from individual activities and behaviors to higher-level logical pluralism $[19,43,44]$. The present study uses these features to understand how stakeholders and institutions influence one another during organizational EAA. The paper focuses on four dimensions of institutional logic to understand situations where these logics are likely to influence the EAA process: (1) the principles that guide activities and embody the institution's goals and values, (2) the assumptions that underlie these principles, (3) people's identity formed by institutional logics, and (4) the domain in which people practice $[19,21,22]$.

\section{Research methods}

\section{Methodology}

This research uses an interpretive approach to understand the natural setting of EAA through a case-study approach $[45,46]$. Orlikowski and Baroudi argue that this approach helps to "understand how members of a social group, through their participation in social processes, enact their particular realities and endow them with meaning, and to show how these

meanings, beliefs and intentions of the members help to constitute their social action" [47; $p$. 14]. The case-study approach also helps to understand phenomena that cannot be studied outside the case-study context and when boundaries are unclear [48]. The case-study approach helps to understand which factors influence the EAA through examining stakeholders' behaviors and activities during the adoption process. 
Two cases within a single country (Vietnam) were chosen. These cases suited the research objective and helped in comparing the findings in order to gain insights into various phenomena [49], as well as multiple cases help us better comparison the findings. In addition, the people responsible for EAA in these cases allowed the researcher to access all necessary resources, official documents, and secondary data and to conduct interviews with the informants.

\section{The case and its context}

Vietnam has a population of around 90 million people as of 2018. The Vietnamese government sees EA as an approach to assist administrative reform and to ensure effective and efficient governance in state agencies $[12,50]$, although the government lacks concrete policies to guide state agencies in EAA, and EA usage is not legally compulsory. This leads to different agencies using different EAA approaches, frameworks, and standards. As a result, agencies face significant challenges in their EA projects, as the projects often fail to meet organizations' objectives. This research examines the story behind these challenges by focusing on two cases within the country.

\section{Case 1}

Coda (a pseudonym) is a province whose EA project was established in 2012; the scope of the project covered all agencies within Coda. The EA project's aims were to help the province reform administrative services and procedures and to increase IS interoperability between inter- and intra-province agencies. The three main stakeholder groups involved in the project were senior managers, project members, and users. The EA products included planning, strategy for IT applications within agencies, and a new model for administrative services (CPS model), including hardware and. Table 1 shows the main activities and timelines of the project. 
Table 1. The main timeline in the EAA process at Coda

\begin{tabular}{|l|l|}
\hline Timeline & Main activities \\
\hline $\begin{array}{l}\text { February 2012- } \\
\text { June 2013 }\end{array}$ & $\begin{array}{l}\text { Standardized public services and administrative procedures (e.g., ISO) by establishing a } \\
\text { CPS as a new model for public services. }\end{array}$ \\
\hline $\begin{array}{l}\text { June 2013-March } \\
2014\end{array}$ & $\begin{array}{l}\text { Successfully implemented EA products in 5 agencies, including standardized } \\
\text { administrative procedures and public services; digitalized and went live with } 457 \text { public } \\
\text { services. }\end{array}$ \\
\hline $\begin{array}{l}\text { March 2014- } \\
\text { October 2015 }\end{array}$ & Expanded 15 agencies using EA products; digitalized and went live with 965 services. \\
\hline October 2015 & The central government approved Coda's approach and EA products. \\
\hline
\end{tabular}

\section{Case 2}

Mocha (a pseudonym) is a ministry whose EA project had similar objectives to Coda's: enhancing the use of ICTs in stage agencies, reforming administrative procedures, and improving the delivery of services to enterprises and citizens. The project's scope covered all agencies within Mocha. Although Mocha had similar aims to Coda when the EA project started, Mocha's EA products were different. Mocha's EA products included strategic planning, such as standards and frameworks (e.g., architectures), that agencies within Mocha could apply in the future. The EA products also included action plans, a proposed egovernment model, and various suggested flagship projects. The three groups involved in the project were senior managers, the project team, and users. Table 2 shows the main activities and timelines of the project.

Table 2. The main timeline in the EAA process at Mocha

\begin{tabular}{|l|l|}
\hline Timeline & Main activities \\
\hline $\begin{array}{l}\text { February 2012- } \\
\text { December 2013 }\end{array}$ & $\begin{array}{l}\text { Established EA products, including frameworks and standards for IT applications } \\
\text { in agencies within Mocha. }\end{array}$ \\
\hline $\begin{array}{l}\text { December 2013-April } \\
2015\end{array}$ & $\begin{array}{l}\text { Justified EA products, including standards and frameworks; EA products could } \\
\text { not be used in practice. }\end{array}$ \\
\hline April 2015 & $\begin{array}{l}\text { The EA products would only be approved upon the project's completion and could } \\
\text { not be used in practice. }\end{array}$ \\
\hline
\end{tabular}

\section{Data collection and analysis}

The data-collection protocol followed the guidance of Stake (2005) and Walsham (1995) [45, 46]. The informants were provided with all information related to the study, including objectives, research ethics, and estimated times and places. Because the informants were 
stakeholders (management teams, project teams, and users) who played key roles in EA project life-cycles, they could provide reliable information. A total of 24 interviews were conducted from June to September 2015 and from July to August 2016 to capture informants' everyday work. The interviews ranged from $\sim 45$ minutes to $\sim 60$ minutes (see Appendix).

Semi-structured interviews with open-ended questions with themes were used. Although the data collection was guided by initial theoretical lenses, the theory was used in very loose ways [46]. The interviews were tape-recorded and subsequently transcribed; notetaking was used to keep the data collection on track. The saturation condition was reached once new interviewees could no longer supply new insights [46].

The first interview was begun with the CIO in each case by introducing the research aims, asking about the case and the CIO's position, and determining the stakeholders and agencies and their main activities related to the projects. These steps provided an overview and timeline of the project and related activities and helped us to select the right stakeholders for in-depth interviews. Interviews were then conducted with the management team, project team, and users, especially on issues related to their activities and experiences with the projects.

Secondary data was also used (e.g., official policies, project documentation, official press releases, and memos) as well as informal observations. These activities allowed for data triangulation to minimize bias. More than 100 secondary documents from both cases were obtained.

Several coding techniques and activities were used for data analysis. The interview transcripts were moved to ATLAS.ti software, which was used to code the data and to systematically locate, code, and annotate the findings. Institutional theory was used to understand the adoption process and its outcomes [46]. A coding unit was defined as texts in transcripts that were no smaller than a sentence and no longer than a paragraph. Single 
coding units could be assigned using multiple codes. The coding process was also used on the secondary data, which helped to reduce bias; triangulation was also used by constantly crosschecking between notes, secondary data, and interview transcripts.

The data analysis was finished once no new patterns emerged from the data sources. These steps were done according to Eisenhardt's guidelines [51]. Several activities were used, such as comparing the findings with the literature.

\section{Findings}

Based on the institutional view and the stakeholders' behavior, activities, norms, and beliefs observed in the data, three dominant logics were identified as influencing the adoption process. These logics came from organizational management, who decided to use EA in their organizations; the project teams, who deployed EA functions and features into real-life practices; and users, who used EA products or were affected by the adoption process.

\section{Managerialism logic}

The evidence from the data indicate that an institutional logic was associated with organizational management (e.g., managerialism logic) that influenced EAA; the characteristics of this logic are shown in Table 3. The two cases examined in this study had similar environments and aims when adoption commenced. For example, they had similar political and legislative systems, and their EAA aimed to promote electronic governance, increase IS interoperability among agencies, and encourage the usage of IT applications in agencies and services. These aims aligned with the central government's master plan for IT applications in state agencies during 2011-2015. Decision number1605/QD-TTg (by the the premier minister) states that one goal is to encourage state agencies to use e-government (such as online services and interoperability among organizations) to reform administrative 
procedures in order to increase productivity, transparency, efficiency, and effectiveness and

to reduce operational costs.

Table 3. Dimensions in managerialism logic at Coda and Mocha

\begin{tabular}{|c|c|c|c|}
\hline & $\begin{array}{l}\text { Characteristics } \\
\text { (Coda) }\end{array}$ & $\begin{array}{l}\text { Characteristics } \\
\text { (Mocha) }\end{array}$ & Selected quotations \\
\hline 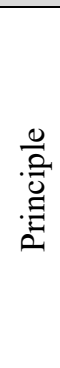 & $\begin{array}{l}\text { Improving online services; } \\
\text { increasing interoperability } \\
\text { associated with reforming } \\
\text { administrative procedures and } \\
\text { services }\end{array}$ & $\begin{array}{l}\text { Improving online services; } \\
\text { increasing interoperability } \\
\text { associated with reforming } \\
\text { administrative procedures } \\
\text { and services }\end{array}$ & $\begin{array}{l}\text { "encourage state agencies using IT } \\
\text { applications for their services" } \\
\text { (Decision No.1605/QD-TTg). } \\
\text { "encourage state agencies using new } \\
\text { IT/IS approaches as means for } \\
\text { administrative reforms" (Res. No. } \\
\text { 30c/NQ-CP). }\end{array}$ \\
\hline 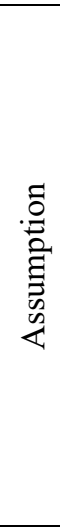 & $\begin{array}{l}\text { Achieving online services } \\
\text { through reform and standard } \\
\text { administrative procedures and } \\
\text { services; } \\
\text { achieving interoperability } \\
\text { through applying established } \\
\text { industrial technology and } \\
\text { products }\end{array}$ & $\begin{array}{l}\text { Achieving online services } \\
\text { and interoperability through } \\
\text { standardized IT and } \\
\text { frameworks }\end{array}$ & $\begin{array}{l}\text { "Reform and standardize [ISO } \\
\text { standards] administrative procedures } \\
\text { [and] services are key [project aims]. } \\
\text { Then, I think technology will help } \\
\text { with interoperability" (CIO, Coda). } \\
\text { "We aim to build a list of standards } \\
\text { so that every new IS has to comply } \\
\text { with them; a framework will help } \\
\text { agencies have a view on what they } \\
\text { invest in" (senior manager, Mocha). }\end{array}$ \\
\hline 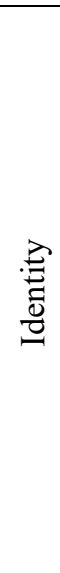 & $\begin{array}{l}\text { Reform administrative } \\
\text { procedures related to services } \\
\text { sections/agencies; standardize } \\
\text { business services for internal } \\
\text { and external customers; } \\
\text { build IT platforms for business } \\
\text { services (e.g., hardware, } \\
\text { software, data center, cloud } \\
\text { services) }\end{array}$ & $\begin{array}{l}\text { Propose conceptual } \\
\text { framework for e- } \\
\text { government and IT } \\
\text { standards }\end{array}$ & $\begin{array}{l}\text { "With the EA products we've used, } \\
\text { we can know the performance and the } \\
\text { status of applications at any time ... } \\
\text { thanks to CPS models and the } \\
\text { smoothness of procedures and } \\
\text { services" (CIO, Coda). } \\
\text { "Every new IS project now has to } \\
\text { comply with the list of [IT] standards } \\
\text { that they will be using in their } \\
\text { products" (enterprise architect, } \\
\text { Mocha). }\end{array}$ \\
\hline 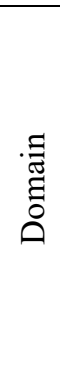 & $\begin{array}{l}\text { All agencies related to } \\
\text { procedures and services }\end{array}$ & $\begin{array}{l}\text { Mainly found in the IT } \\
\text { agency }\end{array}$ & $\begin{array}{l}\text { "All work related to services } \\
\text { [procedures] was affected by the } \\
\text { projects" (project manager, Coda). } \\
\text { "My work routine is similar to what it } \\
\text { had been; the IT department was } \\
\text { responsible for the EA project" (civil } \\
\text { servant, Mocha). }\end{array}$ \\
\hline
\end{tabular}


In the view of institutional theory, both cases attempted to improve online services and increase interoperability capabilities associated with the reform of administrative services. The data showed that both cases had chosen EA as a new approach for their businesses independently and were not influenced by the government. The government had no role in selecting frameworks, architectures, or products. Although both cases had similar principles, they had different assumptions about EA through senior managers' perceptions and expectations toward how EA could help in practice.

In particular, Coda assumed that the condition for successfully improving online services would be met once agencies reformed their administrative procedures and standardized their business services and that interoperability could be achieved through adopting well-known industrial technology (e.g., service bus technology). This assumption led Coda to establish a team to work on standard administrative procedures and services. As a result, in June 2013, Coda standardized its procedures and services and established a new administrative model (the CPS model) based on these standardized procedures and services. Starting in June 2013, citizens and enterprises simply had to visit one agency (the CPS) for their applications only once, in comparison to several times through many agencies before. The main challenge in this case was conflicts with internal users, who were affected by the EAA: their power was reduced, and their jobs were threatened. As the senior manager stated,

“... difficult part is that the tasks relate to reforming administrative procedures and business services, because they influence the users, who had benefits and power in the previous model."

Mocha had a different assumption: to achieve their principles, they had to focus on frameworks and standards. Interestingly, Mocha did not pay attention to how to adopt EA in an appropriate way so that it could bring the highest value. They appeared to have joined the bandwagon because other agencies within the country were using EA. In other words, they 
wanted to mimic other approaches but did not thoroughly consider their environment, structures, and capabilities. As the CIO put it:

"We had two models that we could approach for our case ... we finally chose the US approach [federal enterprise architecture, or FEA], as it was used by the [US federal] government."

With these assumptions in mind, Mocha lacked concrete action plans and only focused on frameworks and standards as EA products. The domain of this approach thus primarily involved the IT agency. An enterprise architect (ET) at Mocha noted that

"... we tried to publish the list of IT standards and frameworks that, in the future, agencies [within Mocha] could comply with for their IT applications; the [proposed] frameworks use a similar approach as the US FEA."

Paradoxically, Coda's domains ranged from business to technology and took part in many agencies to reform and standardize Coda's administrative procedures and business services. As such, their approach differed from normal IS projects in terms of products, scope, protocol, and management. As the CIO said,

“... this project consists of massive business works, and IT plays a very small part. Our senior managers worked as project managers for the business works. We successfully established a new model [CPS], where all public services will be served. We have a team that came from each agency [within Coda] to standardize the service, and [the IT perspective] is the latest part of this project."

\section{Professionalism logic}

The findings related to institutional logic associated with the project teams (e.g., professionalism logic) are shown in Table 4. Project team members used their skills, knowledge, tools, and techniques to meet project requirements. Project teams arranged and acted accordingly based on the principles they had to establish within the products according to the project's requirements; they also had to deliver products on time because of signed 
contracts. The evidence shows that the professional logic affects the EAA process.

Table 4. Institutional logic of project teams

\begin{tabular}{|c|c|c|c|}
\hline & $\begin{array}{l}\text { Characteristics } \\
\text { (Coda) }\end{array}$ & $\begin{array}{l}\text { Characteristics } \\
\text { (Mocha) }\end{array}$ & Selected quotations \\
\hline 党 & Deliver products on time & $\begin{array}{l}\text { Deliver products on } \\
\text { time }\end{array}$ & $\begin{array}{l}\text { "Our job is to satisfy customers and to be } \\
\text { very flexible about the issues" (ET, Coda). } \\
\text { "The principle of the project is to deliver } \\
\text { products to meet [project] requirements" } \\
\text { (PM, Mocha). }\end{array}$ \\
\hline .0 & $\begin{array}{l}\text { Deliver products based on } \\
\text { contracts; EA product features } \\
\text { can be customized, depending } \\
\text { on customer demands }\end{array}$ & $\begin{array}{l}\text { Deliver strictly } \\
\text { based on contracts }\end{array}$ & $\begin{array}{l}\text { "We can't follow the contract and get the } \\
\text { work done because they don't have any } \\
\text { rules; you should be able to cope with } \\
\text { [requirement] changes" (PM, Coda). } \\
\text { "We strictly follow contracts and hardly ever } \\
\text { accept changes [to the requirements] without } \\
\text { a formal negotiation process" (PM, Mocha). }\end{array}$ \\
\hline 常 & Formal and informal procedures & Formal procedures & $\begin{array}{l}\text { "Sometimes, important decisions are made } \\
\text { outside the offices" with customers (ET, } \\
\text { Coda). } \\
\text { "We have to follow the process of this } \\
\text { project, both from the sponsor's and our } \\
\text { guidelines" (Senior manager, Mocha). }\end{array}$ \\
\hline 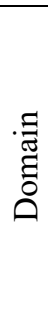 & $\begin{array}{l}\text { Flexible project management } \\
\text { approach }\end{array}$ & $\begin{array}{l}\text { Professional project } \\
\text { management } \\
\text { standards }\end{array}$ & $\begin{array}{l}\text { "Our team's work is related to all agencies, } \\
\text { and their services are a part of our duties" } \\
\text { (i.e., they cannot simply apply professional } \\
\text { standards for every item of work) (PM, } \\
\text { Coda). } \\
\text { "We can't work with other departments } \\
\text { when we're not familiar with" their } \\
\text { procedures and methods (ET, Mocha). }\end{array}$ \\
\hline
\end{tabular}

A formal project management protocol was used among Mocha's EA project team, which meant that all steps and activities relevant to the project followed standards and professional practices. As a result, project schedules, budget plans, and human-resource plans were strictly controlled and approved. The problem was that, in general, formal processes do not work well in organizations when everything is not standardized and professional. In that sense, the professional experiences, skills, and expertise of the project team members caused many challenges. As the CIO stated,

\footnotetext{
“We can't use international experts' knowledge effectively, because their comments and ideas are very difficult to apply in terms of implementation in the future and are unfeasible. They don't seem to understand our status and environment."
} 
The contradiction was that the organization seemed to be aware of this problem but were unable to change, because the project had been granted by and was controlled by sponsors. The project management thus had to follow international standards. Mocha was also unable to find an appropriate way to measure and evaluate their proposal regarding standards and frameworks. For example, they struggled to evaluate which frameworks were good or bad for them. As the PM said,

"The product is about documents, whether you like it or not, so the project team and other related agencies rarely agree" on the project's products and features.

There is an evidence of contradictions between managerialism and professionalism logic. For example, the project team at Mocha was quite confident in its expertise and experiences and believed that the authority should consider and accept their proposed products with minor changes. However, the authority was concerned that their proposal may not be feasible when it comes to implementation to real life, as the senior manager voiced,
"I worry about how they brought [the US FEA] approaches as references for our standards. If standards were too complicated and strict, this could increase costs [when it deploys] because agencies have to invest money and resources to comply with them."

As a result, the authority argued that they cannot accept the EA products proposed by the project team, because they did not see it was feasible. Due to the disagreements between managers and project team about products features, the project performance was over budget and time. In contrast, Coda used mixed formal and informal approaches, which helped to ensure flexibility and creativity. As the PM said,

\footnotetext{
"the formal approach will work well if it is professional and [is used] in a highly institutionalized organization; what we see in EA practice is case by case, so that we use this [informal and formal] approach."
} 
With this identity in mind, Coda focused on the managerial competence of the project team rather than technical competence, as Mocha did. As a result, Coda was able to address problems not only common to IT projects, but problems that were unique to Coda's EA project.

\section{Users logic}

Table 5 presents the institutional logic associated with users. EA users included citizens (e.g., using EA products for applications on the front end), civil servants (e.g., using EA products to process applications on the back end), managers (e.g., using EA as tools to manage their businesses).

Table 5. Institutional logic of users

\begin{tabular}{|c|c|c|c|}
\hline & $\begin{array}{l}\text { Characteristics } \\
\text { (Coda) }\end{array}$ & $\begin{array}{l}\text { Characteristics } \\
\text { (Mocha) }\end{array}$ & Selected quotations \\
\hline 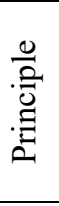 & Easy to use and control & Easy to use & $\begin{array}{l}\text { "We aim to control the process of } \\
\text { services and make them easy to use" } \\
\text { (PM, Coda). } \\
\text { "The IS [at Mocha] aims for ease of use } \\
\text { for all users" (CIO, Mocha). }\end{array}$ \\
\hline 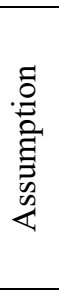 & $\begin{array}{l}\text { Follow the standard } \\
\text { procedures and services }\end{array}$ & $\begin{array}{l}\text { New IS follows IT } \\
\text { standards and } \\
\text { frameworks }\end{array}$ & $\begin{array}{l}\text { "We aim for [EA] products that will help } \\
\text { our admins achieve ISO standards" for } \\
\text { services and procedures (PM, Coda). } \\
\text { "I don't think the project will affect my } \\
\text { work in the short term," since the current } \\
\text { systems had not yet changed (IT } \\
\text { specialist, Mocha). }\end{array}$ \\
\hline 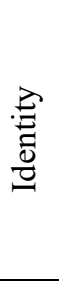 & $\begin{array}{l}\text { Working performance (e.g., } \\
\text { number of applications per } \\
\text { day, time to process, tracking } \\
\text { of work) }\end{array}$ & $\begin{array}{l}\text { Checking compliance } \\
\text { status of new IS with } \\
\text { standards and framework }\end{array}$ & $\begin{array}{l}\text { "... many [colleagues] did not want [to } \\
\text { be involved in the project] because they } \\
\text { have to follow performance-based" } \\
\text { standards (civil servant, Coda). } \\
\text { "We have the list of standards in hand ... } \\
\text { [and] the suppliers have to comply with } \\
\text { this" list (PM, Mocha). }\end{array}$ \\
\hline • ڤี & $\begin{array}{l}\text { Service areas (e.g., tax, } \\
\text { finance, or immigration } \\
\text { services) }\end{array}$ & IT-technical-related areas & $\begin{array}{l}\text { "The project affects all departments } \\
\text { related to services provided to } \\
\text { customers" (ET, Coda). } \\
\text { "... we prefer [EA projects that] focus } \\
\text { more on technical issues" rather than } \\
\text { including the business (civil servant, } \\
\text { Mocha). }\end{array}$ \\
\hline
\end{tabular}

The data showed that internal users - those who used or were affected by EA productsinfluenced the project outcomes. They tended to refuse the changes, instead using old 
familiar practices in their routines, or they took part in negotiations about the products (as with Coda). Mocha showed uncertainty about users' roles related to project outcomes, however, which might have been because the EA products used at Mocha were standards and frameworks. No short-term user impacts on project outcomes could be identified as a result. Coda's assumption was that users (e.g., civil servants and citizens) have to follow standard procedures and services so that the services will be easy to use and so that leaders can easily manage and control the working status from both sides. For example, they could easily learn the performance of both external users (e.g., citizens and enterprises) and internal users (e.g., civil servants and IT specialists within Coda). This caused a conflict of interests for some users. For example, they needed to learn more skills to adapt to requirements within new procedures and services. As a civil servant said,

“... when they gave us a survey about the program, my colleague filled in the form with her negative opinion about the EA adoption [at Coda], her reason being that she didn't want to change her routines and job role."

\section{Discussion}

\section{Interplays between institutional logics}

The managerialism logic (i.e., among senior managers) played a crucial role at Coda in terms of choosing approaches, organizing the EA team, legitimizing the results, and revising the EA directions and products when needed. In contrast, the senior managers at Mocha had less power. As a result, the Mocha senior managers' decisions were influenced by the project members, as well as by the sponsors' policies, in negative ways. In other words, the professionalism logic was more influential than the managerialism logic at Mocha compared to Coda, which led to the processes and outcomes seemingly not achieving their objectives. In that sense, the managerialism logic seemed to dominate EAA at Coda. 
Both cases had similar situations, in that the government lacked policies that would institute pressure to deploy EA within agencies. In that sense, external pressure was not evident in EAA. The decision to adopt EA came from managerial expectations and assumptions about EA, which meant that individuals' or stakeholders' norms, beliefs, and practices were a major consideration in the EAA process [52]. For example, the top managers at Coda sought a new approach to assist in administrative reforms and to improve Coda's services. They expected that EA could be a promising solution. This managerial expectation affected stakeholders' behavior and activities in multiple levels and across organizations and functions. Top managers also clearly supported activities related to reforming administrative procedures and improving business services. In other words, the managerialism logic at Coda clearly affected other logics toward EAA, including approaches, products, and directions.

In contrast, Mocha seemed to mimic the way EA was used in developed countriesthat is, with a focus on standards and frameworks $[2,35,50]$. They did not consider why these countries had focused on standards and frameworks; for example, these countries had stable administrative procedures, structures, and business services in place (and thus their EA projects focused on those aspects), while Mocha did not.

Interestingly, the Coda project team members seemed to be less experienced and professional than their counterparts at Mocha, who had more international expertise and experience. This international expertise affected Mocha negatively, however, because project teams used their experiences and pushed to get things done in order to maximize their benefits (e.g. in time, effort, and ease of delivery); they also convinced the top managers at Mocha to use standards and frameworks for their EA products. This situation meant that EAA at Mocha was heavily influenced by the professional logic. This logic also influenced the managerialism logic in terms of goals, approaches, and directions. As a result, the managerialism logic seemed comparatively less important at Mocha than at Coda. 
The situation described here indicates that the adoption process influenced multiple coexisting logics, such as the managerialism and professionalism logic. These logics appeared differently in the two cases. Decision-making at Coda were made at the very top level of management, which represents the dominance of the managerialism logic. Their decisions did not seem to be influenced by lower levels, whereas the top management at Mocha was influenced by other groups, such as project teams. The professionalism logic had a strong influence on managerialism logics at Mocha.

Depending on various fields of practice, the logics that appeared in different stakeholder groups were also indicated in other areas. For example, five logics in IS innovation are typically used at universities, including the market, teaching, IS profession, corporate, and research logics [53]. Bunduchi has also stated that the configurations between these logics create the spaces that the IS innovation occupies [53].

Two other logics have been identified in health-management ISs - the network and hierarchical-bureaucratic logics — and the formal logic embedded in network technologies disrupts and challenges the existing logic [54]. In a similar vein, the bureaucratic logic and managerialism logic have been found in trade-related ISs in Ghana, where the tensions and contradictions between the two logics were found to have enabled change in the bureaucracy [55].

\section{How adoption is influenced by institutional logics}

This section discusses how, even though the two cases had similar starting situations and aims, the outcomes differed. Multiple logics occurred simultaneously within the cases during the adoption process, and stakeholders responded differently due to logic incomparability and conflict [56]. These factors were reconciled and negotiated among the stakeholders, thus leading to potential changes in the process that ultimately affected the projects' outcomes. 
The stakeholders in the management and project teams showed several differences at Mocha. The stakeholders in each group had different views, goals, strategies, activities, behaviors, and core work practices, which were consistent with the logic to which they belonged. For example, while the project members advocated more rigorously sticking to project tasks and project-management procedures and policies, the senior managers sought flexible and changeable management and tasks, depending on the uncertainty of their environment. As a result, two core institutional logics - the professionalism and managerialism logics — did not agree in terms of final EA products and features. This situation meant that the products could not be used in reality, as the authorities had not approved or legitimated them. This situation was similar in other areas, such as within conflicts between former bankers and social workers because of the two groups' different goals and practices [57].

The situation differed at Coda. Although multiple core logics were involved in the process of adoption (the users, professionalism, and managerialism logics), the logics were more compatibility, meaning that conflicts between these logics were minimal. As a result, the views, goals, strategies, activities, behaviors, and core work practices among different groups saw little conflict. For example, while project members could only follow their contracts and professional procedures toward the EA project, they also advocated that they should follow the managerialism logic. As a result, they interpreted and customized the projects' tasks in flexible ways, depending on management demands. These kinds of multiple logics that can provide compatible prescriptions for action could also be seen elsewhere, such as in the two logics from state actors (i.e., state logic) and child-care actors (i.e., professional logic), which were compatible with goals and practices [58].

Unlike other IS approaches such as the enterprise system, which is best suited for highly explicit procedures and repetitive routine applications [59], EA is a complicated 
domain with many schools of thoughts [60]. EAA also promises optimistic outcomes but appears to lack appropriate guidance for achieving results [23], thus leading to project teams (i.e., the professionalism logic) and adopters (the managerialism logic) being very flexible with standards, approaches, products, and frameworks in comparison to traditional IS, as in Coda. This situation was a source of contradiction and conflict between those stakeholders who took part in EAA. These stakeholders may present or bring different logics to their activities and behaviors toward projects. For example, Mocha chose EA products as standards for IT application and frameworks without a common understanding about what the frameworks were, what they were composed of, or how the frameworks should be adopted to real life $[18,29,60]$. As a result, practitioners struggled to choose an appropriate approach. As the senior manager at Mocha said,
"the literature indicates the advantages of EA, but in practice I can't find examples of successful case studies or appropriate documents [i.e., guidance on EA in practice], such as which approaches and standards are suitable in which environments ... which is a problem."

In summary, the multiple logics found among stakeholders were key to the adoption processes and played important roles in the adoption. When these multiple logics are contradictory and show poor comparability in action (as was the case at Mocha), extensive conflicts in adoption activities and tasks will likely result. In contrast, if those multiple logics are compatible and comparable in action (as in Coda), minimal conflicts in adoption activities and tasks are to be expected. Table 6 summarizes the two logics and their features in EAA.

Table 6: Logics' features and the EAA process

\begin{tabular}{|l|l|l|l|}
\hline & Type & Feature & Result \\
\hline Coda & $\begin{array}{l}\text { Minimal } \\
\text { conflict }\end{array}$ & $\begin{array}{l}\text { - Logics provide compatibility toward project activities } \\
\text { among stakeholders } \\
\text {-One logic becomes dominant }\end{array}$ & $\begin{array}{l}\text { Clear results and } \\
\text { signals of success }\end{array}$ \\
\hline Mocha & $\begin{array}{l}\text { Extensive } \\
\text { conflict }\end{array}$ & $\begin{array}{l}\text { - Logics are contradictory toward project activities among } \\
\text { stakeholders }\end{array}$ & Signals of failure \\
\hline
\end{tabular}




\begin{tabular}{|l|l|l|l|}
\hline & & - Incompatible logics maintained & \\
\hline
\end{tabular}

\section{Conclusion}

This paper contributes to the literature by explaining how enterprise architecture adoption (EAA) is affected by different factors when organizations adopt EA. First, when the EAA is guided by compulsory policies, as is the case with the US federal government (such as the 1996 Clinger-Cohen Act or the 2002 E-Government Act), agencies must comply with certain specific institutional conditions and environments when they adopt EA [7, 23]. As a result, the outcomes of EAA can be predictable in terms of frameworks, products, and approaches [36]. In contrast, when the adoption is not guided by policy (as in this research), the cognitive-cultural beliefs, activities, and norms embedded in individuals' different logics influence the process of adoption, and ultimately EAA outcomes.

Second, more than one logic could simultaneously exist in EAA, including the managerialism, professionalism, and user logics. If coexisting logics have minimal conflicts, then more compatibility will be likely between different stakeholders toward adoption activities. This situation could result in better outcomes for the EAA, as was the case at Coda in the present study. In contrast, the more extensively that different logics conflict, the more stakeholders will be incompatible in their actions. When stakeholders are embedded in these logics, if the logics compete, contradict, or conflict with one another, then stakeholders' activities and behaviors toward their practices will be affected [57] and EA will ultimately be affected in practice, as was the case with Mocha in this study.

Third, this study has indicated that the results of interplay among institutional logics lead to different practices and, ultimately, outcomes in EAA. One of the factors to explain the differences in logics and practices in EAA was found to be an immature EA discipline itself, which led to differences in managerial expectations and assumptions about EA. Geography 
explains the principle differences in logics and practices in the financial field [20], and time and the landscape are sources of differences in IS innovations [53].

\section{Practical contributions}

The study has also made several practical contributions. First, managers should consider stakeholders' logics when they adopt EA. Doing so could help practitioners predict stakeholders' behaviors and activities toward adoption activities, which could in turn help practitioners find solutions or approaches to managing potential challenges, ultimately helping senior managers achiever better adoption outcomes.

Second, several countries are planning to adopt EA in the near future [50]; these countries could look to the logics and their features explained in this research as lessons learned for their practices. For example, managers should focus on their own experiences and capabilities when choosing appropriate approaches, frameworks, and products. They should also identify their core logics and seek to minimize conflicts among those logics; they should not depend solely on their professional opinions or expertise, since doing so could lead to inefficient adoption, as was the case with Mocha in this study.

Third, managers should pay attention to the characteristics of EA and align them with their capabilities before deciding to adopt. This will help them prepare for and minimize any risks in adoption. EA also covers multiple streams, meanings, and domains that lack international agreements on standards, frameworks, or approaches $[12,60]$. This situation contrasts with traditional IS practices, such as enterprise systems, which are best suited to highly explicit procedures and repetitive routine applications [59].

\section{Limitations and future work}

The study does have limitations; it focused on the case context, for example, which may limit generalization. But although the scope of validity is important, the context is crucial in IS 
research [63]. In that sense, one could argue that the findings in this study could be generalized to apply to other cases with similar environments. This study offers only a starting point to understanding which factors influence EAA outcomes.

Opportunities for future work include comparing different geographic and cultural settings in order to understand which factors influence EAA - both in terms of intra- and inter-organizational relations, conducted simultaneously at multiple levels and in different contexts - to ensure better understanding and improved generalizability of the findings. Future studies could also focus on EAA contradictions and decoupling as part of their analyses to achieve a better understanding of stakeholders' activities and behaviors, and how these factors affect outcomes. Future studies could also focus on the impact of EAA on other perspectives, such as the management of change and logics of change, and compare these perspectives to those used in other disciplines, such as finance or economics.

\section{Acknowledgments}




\section{References}

[1] Kappelman, L.A. and J.A. Zachman, The enterprise and its architecture: ontology \& challenges. Journal of Computer Information Systems 2013. 53(4): 87-95.

[2] Simon, D., K. Fischbach, and D. Schoder, An exploration of enterprise architecture research. CAIS, 2013. 32(1).

[3] Ross, J.W., P. Weill, and D.C. Robertson, Enterprise architecture as strategy: creating a foundation for business execution. 2006: Harvard Business School Press.

[4] Magoulas, T., et al., Alignment in enterprise architecture: a comparative analysis of four architectural approaches. Electronic Journal Information Systems Evaluation, 2012. 15(1): 88-101.

[5] Alwadain, A., et al., Empirical insights into the development of a service-oriented enterprise architecture. Data \& Knowledge Engineering, 2015. 105: 39-52.

[6] Iyamu, T., Understanding the complexities of enterprise architecture through structuration theory. Journal of Computer Information Systems, 2017.

[7] Dang, D.D. and S. Pekkola, Institutionalising enterprise architecture in the public sector in Vietnam, in the 24th ECIS. 2016.

[8] Kaisler, S.H., F. Armour, and M. Valivullah. Enterprise architecting: critical problems. In 38th HICSS. 2005.

[9] Schöenher, M., Towards a common terminology in the discipline of enterprise architecture. ICSOC 2008 Workshops. Lecture Notes, Springer, 5472/2009, 2009.

[10] Iyamu, T. and L. Mphahlele, The impact of organisational structure on enterprise architecture deployment. Journal of Systems and Information Technology, 2014. 16(1): 2-19.

[11] Bloomberg, J. Is enterprise architecture completely broken? 2014 [cited 2015 August 8]; Available from: http://www.forbes.com/sites/jasonbloomberg/2014/07/11/isenterprisearchitecture-completely-broken/.

[12] Dang, D.D. and S. Pekkola, Problems of Enterprise Architecture Adoption in the Public Sector: Root Causes and Some Solutions, in Information Technology Governance in Public Organizations: Theory and Practice, L. Rusu and G. Viscusi, Editors. 2017, Springer.

[13] Lange, M., J. Mendling, and J. Recker, An empirical analysis of the factors and measures of Enterprise Architecture Management success. EJIS, 2015. 25(5): 411-431.

[14] Shaanika, I. and T. Iyamu, Deployment of enterprise architecture in the Namibian government: the use of activity theory to examine the influencing factors. EJISDC, 2015. 71(6): 1-21.

[15] Schmidt, C. and P. Buxman, Outcomes and success factors of enterprise IT architecture management: empirical insight from the international financial services industry. EJIS, 2011. 20: 168-185. 
[16] Hauder, M., et al. An examination of organizational factors influencing enterprise architecture management challenges. In 21st ECIS. 2013.

[17] Weiss, S., S. Aier, and R. Winter. Institutionalization and the effectiveness of enterprise architecture management. In 34th ICIS, Milan 2013. 2013.

[18] Bui, Q.N., Evaluating enterprise architecture frameworks using essential elements. CAIS, 2017. 41,6.

[19] Berente, N. and Y. Yoo, Institutional contradictions and loose coupling: Post implementation of NASA's enterprise information system. ISR, 2012. 23(2): 376396.

[20] Cloutier, C. and A. Langley, The logic of institutional logics: insights from french pragmatist sociology. Journal of Management Inquiry, 2013. 22(4): 360-380.

[21] Thornton, P.H. and W. Ocasio, Institutional logics, in The SAGE Handbook of Organizational Institutionalism, R. Greenwood, et al., Editors. 2008.

[22] Friedland, R. and R.R. Alford, Bringing society back in: symbols, practices, and institutional contradictions, in The New Institutionalism in Organizational Analysis, W.W. Powell and P.J. DiMaggio, Editors. 1991, University of Chicago Press. p. 232-263.

[23] Dang, D.D., Enterprise Architecture Institutionalization: A Tale of Two Cases, in the 25th ECIS. 2017.

[24] Banaeianjahromi, N. and K. Smolander, Lack of communication and collaboration in enterprise architecture development. Information Systems Frontiers, 2017: 1-32.

[25] Armour, F.J., S.H. Kaisler, and S.Y. Liu, Building an enterprise architecture step by step. IT Professional, 1 (4), 31-39., 1999.

[26] Iyamu, T. The Factors affecting institutionalisation of enterprise architecture in the organisation. In IEEE CEC, p. 221-225. 2009.

[27] Rahimi, F., J. Gøtze, and C. Møller, Enterprise architecture management: toward a taxonomy of applications. CAIS, 2017. 40.

[28] Freeman, E., Strategic management: a stakeholder approach. 1984: Pitman. 276.

[29] Iyamu, T., Implementation of enterprise architecture through the Zachman framework. Journal of Systems and Information Technology, 2018.

[30] Löhe, J. and C. Legner, Overcoming implementation challenges in enterprise architecture management: a design theory for architecture-driven IT Management. Information Systems and E-Business Management, 2014. 12(1): 101-137.

[31] Weerakkody, V., M. Janssen, and K. Hjort-Madsen, Integration and enterprise architecture challenges in e-government: A European perspective. International Journal of Cases on Electronic Commerce, 2007.

[32] Bruls, W.A.G., et al., Domain architectures as an instrument to refine enterprise architecture. CAIS, 2010. 27.

[33] Dang, D.D., Enterprise architecture in the public sector: adoption and institutionalization. Tampere University of Technology: Publication, Vol. 1544, 2018. 
[34] Aier, S. and S. Weiss, An institutional framework for analyzing organizational responses to the establishment of architectural transformation, in the 20th ECIS, 2012.

[35] Hjort-Madsen, K., Enterprise Architecture Implementation and Management: A Case Study on Interoperability, in the HICSS-39. 2006.

[36] Hjort-Madsen, K., Institutional patterns of enterprise architecture adoption in government. Transforming Government: People, Process and Policy, 2007. 1(4): 333-349.

[37] Janssen, M. and K. Hjort-Madsen. Analyzing enterprise architecture in national governments: the cases of Denmark and the Netherlands. In the 40th HICSS. 2007.

[38] Hjort-Madsen, K. and J. Pries-Heje, Enterprise architecture in government: fad or future? In the HICSS-42.

[39] Magnusson, J. and A. Nilsson, Infusing an architectural framework with neoinstitutional theory: reports from recent change management initiatives within the Swedish public administration, in the 39th HICSS. 2006.

[40] Scott, W.R., Institutional theory, in Encyclopedia of Social Theory. 2005, Thousand Oaks, CA: Sage. p. 408-14.

[41] DiMaggio, P.J. and W.W. Powell, The iron cage revisited: institutional isomorphism and collective rationality in organizational fields. American Sociological Review, 1983. 48(2): 147-160.

[42] Mignerat, M. and S. Rivard, Positioning the institutional perspective in ISR. Journal of Information Technology, 2009. 24(4): 369-391.

[43] Qiu, Y., A. Gopal, and I.-H. Hann, Logic pluralism in mobile platform ecosystems: a study of indie app developers on the iOS App Store. ISR, 2017: 125.

[44] Volkoff, O., D.M. Strong, and M.B. Elmes, Technological embeddedness and organizational change. Organization Science, 2007. 18(5): 832-848.

[45] Stake, R.E., Qualitative case studies, in The SAGE Handbook of Qualitative Research 3rd edition, N.K. Denzin and Y.S. Lincoln, Editors. 2005, Saga. p. 443466.

[46] Walsham, G., Interpretive case studies in IS research: nature and method. EJIS, 1995. Vol. 4: 74-81.

[47] Orlikowski, W.J. and J.J. Baroudi, Studying information technology in organizations: research approaches and assumptions. ISR, 1991. 2(1): 1-28.

[48] Benbasat, I., D.K. Goldstein, and M. Mead, The case research strategy in studies of information systems. MIS Quarterly, 1987. 11(3): 369-386.

[49] Myers, M.D., Qualitative research in business and management. 2009, London, UK: SAGA.

[50] Dang, D.D. and S. Pekkola, Systematic literature review on enterprise architecture in the public sector. Electronic Journal of e-Government, 2017. 15(2): 130-154. 
[51] Eisenhardt, K.M., Building theories from case study research. The Academy of Management Review, 1989. 14(4): 532-550.

[52] Almandoz, J., Founding teams as carriers of competing logics: when institutional forces predict banks' risk exposure. Administrative Science Quarterly, 2014. 59(3): 442-473.

[53] Bunduchi, R., Overlapping logics and institutional alignment spaces: Mapping the organisational trajectory of an IS innovation, in the 25th ECIS. 2017.

[54] Asangansi, I., Is mHealth disrupting the status quo? Evidence from implementations highlighting network vs. hierarchical institutional logics. EJISDC, 2016. 72(7): 1-27.

[55] Addo, A.A., Explaining 'irrationalities' of it-enabled change in a developing country bureaucracy: the case of Ghana's Tradenet. EJISDC, 2016. 77(6): 1-22.

[56] York, J.G., T.J. Hargrave, and D.F. Pacheco, Converging winds: logic hybridization in the Colorado wind energy field. Academy of Management Journal, 2016. 59(2).

[57] Besharov, M.L. and W.K. Smith, Multiple institutional logics in organizations: Explaining their varied nature and implications. Academy of management review, 2014. 39(3).

[58] Binder, A., For love and money: Organizations' creative responses to multiple environmental logics. Theory and Society, 2007. 36: 547-571.

[59] Suna, Y. and A. Bhattacherjee, Multi-level analysis in ISR: The case of enterprise resource planning system usage in China. Enterprise Information Systems, 2011. 5(4): 469-494.

[60] Lapalme, J., Three schools of enterprise architecture. IT Professional, 14 (6), $37-$ 43. , 2012.

[61] Lounsbury, M., A tale of two cities: Competing logics and practice variation in the professionalizing of mutual funds. Academy of Management Journal, 2007. 50: $289-307$.

[62] Dahlmann, F. and J. Grosvold, Environmental managers and institutional work: Reconciling tensions of competing institutional logics. Business Ethics Quarterly, 2017. 27(2): 263-291.

[63] Davison, R.M. and M.G. Martinsons, Context is king! Considering particularism in research design and reporting. Journal of Information Technology, 2016. 31(3): 241-249. 
Appendix: Interview guidance (semi-structured, face-to-face interviews)

The guidance was organized into themes, questions, and subjects. During the interview process, follow-up questions were used if necessary.

\begin{tabular}{|l|l|}
\hline Theme & Selected questions or subjects \\
\hline Background & Understanding the interviewees' basic information and projects \\
\hline EAA process & $\begin{array}{l}\text {-What prompted the use of EA? How was the project organized? } \\
\text { How was the informant involved in the project? } \\
\text {-What approaches have been used in the EA project? } \\
\text {-How did the main different interest groups view EA in this } \\
\text { the project? Describe how each project's activities were legitimated } \\
\text { or approved. Who was involved in this aspect? } \\
- \text { Can the project's products be used in practice? How do new EA } \\
\text { features become practices? } \\
\text { - Which approach has been used for the evaluation work? }\end{array}$ \\
\hline Closing & \begin{tabular}{l} 
Other interesting issues, recommended to other interviewees \\
\hline
\end{tabular}
\end{tabular}

\section{List of interviewees at Coda and Mocha*}

\begin{tabular}{|c|c|c|}
\hline Group & Coda & Mocha \\
\hline $\begin{array}{l}\text { Management } \\
\text { team }\end{array}$ & James (CIO/senior manager, 2) & $\begin{array}{l}\text { Larry (senior manager, } 1) \\
\text { Robin (senior manager, } 1) \\
\text { Jack }(\mathrm{CIO}, 2)\end{array}$ \\
\hline Project team & $\begin{array}{l}\text { Daniel (project manager, 2) } \\
\text { Raphael (enterprise architect, 1) } \\
\text { Shaun (enterprise architect, 1) } \\
\text { Hana (enterprise } \\
\text { architect/technical specialist, 1) }\end{array}$ & $\begin{array}{l}\text { Dale (project manager, 2) } \\
\text { Ronald (enterprise architect, 1) } \\
\text { Ted (enterprise architect, 1) } \\
\text { Palma (enterprise architect, 1) } \\
\text { Kai (enterprise architect, 1) }\end{array}$ \\
\hline User & $\begin{array}{l}\text { Angela (1) } \\
\text { Alma (1) } \\
\text { Brad (1) }\end{array}$ & $\begin{array}{l}\text { Calvin (1) } \\
\text { Mark (1) } \\
\text { Daisy (1) } \\
\text { Vanessa (1) }\end{array}$ \\
\hline
\end{tabular}

*Parentheses indicate the interviewee's position and the number of the interview 